\title{
An Economic Analysis of Capsicum Production under Protected Cultivation in North West Region of Tamil Nadu, India
}

\author{
S. Senthilkumar ${ }^{1 *}$, K. R. Ashok ${ }^{2}$, M. Chinnadurai ${ }^{3}$ and S. P. Ramanathan ${ }^{4}$
}

${ }^{1}$ Department of Agricultural Economics, CARDS, TNAU, Coimbatore, Tamil Nadu, India

${ }^{2}$ Department of Agricultural and Rural Management, TNAU, Coimbatore, Tamil Nadu, India

${ }^{3}$ Directorate of Centre for Agricultural and Rural Development Studies, TNAU, Coimbatore, Tamil Nadu, India

${ }^{4}$ Water Technology Centre, TNAU, Coimbatore, Tamil Nadu, India

*Corresponding author

\section{Keywords}

Protected cultivation,

Establishment cost, Cost

of cultivation, Capsicum

economics

Article Info

Accepted:

20 May 2018

Available Online:

10 June 2018

\section{A B S T R A C T}

Protected cultivation or greenhouse cultivation would be the modern approach to produce horticultural crops qualitatively and quantitatively. Also it has been spread extensively world over in the last few decades. In India, production of capsicum found to be around 327 thousand tons from the area of 46 thousand hectare with the productivity of 7108.70 $\mathrm{kg}$ per hectare during the year of 2017. Hence, it is important to examine economic viability of capsicum production under protected method. In this context, a survey was conducted by using pre-tested interview scheduled among the farming community in the North West region of Tamil Nadu. The results of the study indicates that, total investment around Rs.40.67 lakhs per/ $4000 \mathrm{~m}^{2}$ required for erecting polyhouse. The major costs of establishment were incurred on GI frame (72.78 per cent) followed by land levelling and polythene sheet cost (8.15 per cent). The cost $A_{1}$ was higher 55.19 per cent for capsicum cultivation and $\operatorname{cost} \mathrm{B}_{1}$ was cost $\mathrm{A}_{1}$ with including the interest on fixed capital excluding the land was 31.81 per cent of the total cost of production of capsicum cultivation. The cost $\mathrm{C}_{3}$ was Rs.13, 16,996/4000 $\mathrm{m}^{2}$ for capsicum under protected cultivation. The gross return of the cultivated crops found to be Rs. 15,29,502 and Net return Rs. 2,12,506 for capsicum cultivation. The cultivation of capsicum in a polyhouse was found to be highly feasible as reflected in higher values of NPV (Rs. 5.78 lakhs/4000 m²), BCR (1.24) and IRR $(25 \%)$ with payback period of less than three years. High investment cost for establishing poly house followed by lack of technical guidance was most important constrains among the farmers in capsicum production under protected cultivation.

\section{Introduction}

Recent days, protected or greenhouse cultivation of high value vegetables and cutflowers has shown tremendous potential for farmer's wellbeing. The technology developments creating avenues at higher level but also to the growers with the smaller landholdings as the higher productivity levels retain economic relevance to agriculture (Brij bala 2013). Protected cultivation is precise, progressive and parallel agriculture 
encompassing virtually all facets of agriculture rather scrutiny of technical relevance to situations and grower and market economics. Since, protected cultivation would be a vast assembly of diverse aspects of agriculture (Sreenivasamurthy et al., 2007).

The protected cultivation is the most contemporary approach to produce mainly, horticultural crops and have spread extensively world over in the last few decades. It is also known as controlled environment agriculture highly productive, conserve water, land and also protect environment (Jensen 2002). The technology involves the cultivation of horticultural crops in a controlled environment wherein the factors like temperature, humidity, light, soil, water, fertilizers etc. are manipulated to attain maximum produce as well as regular supply of them during off-season. By adopting protected cultivation technology, the growers can look forward to a better and additional remuneration for high quality produce (Rai et al., 2004, Mathura Rai 2012).

The advent of protected cultivation technology in India materialized during the early nineties, post globalization. In India, the area under protected cultivation is presently around 25000 ha while the greenhouse vegetable cultivation area is about 2000 ha. There are constrains in handling protected cultivation. Today Dutch protected cultivation is one of the most intensive farming systems in the world with high levels of output by using the latest technologies (Goncharova 2004).

In the case of capsicum, total production was 327 thousand tons from an area of 46,000 hectare with the productivity of $7108.70 \mathrm{~kg}$ per hectare in India. It is extensively cultivated in Karnataka, Madhya Pradesh, Andhra Pradesh, Maharashtra, Tamil Nadu, Himachal Pradesh, and hilly areas of Uttar Pradesh. Among the states, Karnataka stands first with the area of 4130 ha and production of 81.67 thousand tons followed by Himachal Pradesh with the area of 2500 ha and production of about 58.29 thousand tons. In case of Tamil $\mathrm{Nadu}$, north western region and hilly region of Tamil Nadu produce of 600 tons with the area of 90 ha (Horticultural statistics at a glance 2017).

The cost of the polyhouse structure plays the decisive factor for adoption and sustainability of capsicum production. The cost of a polyhouse mainly depends on the quality of materials used for the structure and glazing and others like drip and mist systems. Polyhouses are of various sizes ranging from 1000 to $10,000 \mathrm{~m}^{2}$ depending on the requirement. Against this background the present study was taken up to examine the economic viability of production of capsicum under protected cultivation in North West region of Tamil Nadu. The specific objectives were: to estimate cost and returns and to study the constraints in capsicum production under protected condition.

\section{Materials and Methods}

A farm level interview was conducted by using pre-tested interview scheduled in the Krishnagiri district of Tamil Nadu to examine the economic and financial feasibility under polyhouse production of capsicum. Among the blocks in Krishnagiri district based on area under cut flowers and capsicum Soolagiri, Thally, Hosur and kelamangalam blocks were selected purposively for the present study. National Horticultural Mission (NHM) beneficiaries of the selected blocks were obtained from the office of Deputy Director of Horticulture, State Department of Horticulture, Krishnagiri. Thereafter, 120 farmers were selected randomly among the four blocks. In Capsicum cultivation under protected cultivation of 30 sample farmers selected for the present study. 
The cost-effective techniques were employed to assess the establishment of poly house structure, cost of cultivation and financial feasibilities. Tabular presentation of cost structure returns and profits were furnished. The collected data were averaged and percentages were compared, contrasted and interpreted. The data were collected from the average size of the polyhouse unit was acres/ $4000 \mathrm{~m}^{2}$. Average life of the polyhouse structure was around five years period. The cost, gross and net returns of capsicum grown in the poly house were estimated using the cost concept approach as given by the Commission on Agricultural Costs and Prices (CACP), Government of India, New Delhi.

Similarly, an attempt was made in the study to estimate the cost of production of capsicum under polyhouse cultivation; provides indication to farmers whether the cultivation of capsicum profit over the market price or not. To assess this, cost of production was estimated by accounting all costs involving in the cultivation crop under polyhouse and prevailing market price assessed and compared. Estimation of cost of production is bit tricky as two types of costs were involved viz. establishment cost and annual production cost. Annul production costs was used directly and it is only a question of apportion the cost of establishment. It is well-known fact that 'depreciation', a systematic and rational process of distributing the cost of tangible assets over the life of assets, is used to apportion the cost. Straight line depreciation method was used in the present study to apportion the total value of the assets like GI pipes, polythene sheets, irrigation equipments, etc., depending on their life span. Once the annual costs of all items were estimated, the cost of production ( $\mathrm{Rs} / \mathrm{kg}$ ) was estimated. The price prevailed in the market during period was also obtained and compared for the profitability of production (Sreedhara et al., 2013).
Economic feasibility of investment on production of capsicum under protected cultivation was evaluated by using project evaluation measures. Payback Period (PBP), Benefit Cost Ratio (BCR), Net Present Value (NPV) and Internal Rate of Return (IRR) were used for project evaluation (Ali et al., 2016).

Except PBP is an undiscounted measure, all others, BCR, NPV and IRR, are discounted measures of project worthiness. A discount rate of 12 per cent was used in the present study to estimate these parameters. The average reference rate of interest given by the different financial institutions for the investment for long term projects was used as a decision criterion for selection of the discount rate (Tarannum et al., 2014).

Garrett's (1977) Ranking Technique was employed in the present study to examine the various constraints in the order of their importance. The respondents were asked to rank the problems in capsicum production. In the Garrett's ranking technique these ranks were converted into percent position by using the formula,

Percent position $=100 *\left(\mathrm{R}_{\mathrm{ij}}-0.5\right) / \mathrm{N}_{\mathrm{j}}$

Where,

$\mathrm{R}_{\mathrm{ij}}=$ Ranking given to the $\mathrm{i}^{\text {th }}$ attribute by the $\mathrm{j}^{\text {th }}$ individual

$\mathrm{N}_{\mathrm{j}}=$ Number of attributes ranked by the $\mathrm{j}^{\mathrm{th}}$ individual.

By referring to the Garrett's table, the per cent positions were estimated and converted into scores. Then the scores of various respondents for each of the factor were added and the mean values were estimated. The mean values thus obtained for each of the attributes were arranged in the descending order. The attributes with the highest mean value was 
considered as the most important one, followed by others in that order.

\section{Results and Discussion}

\section{Cost of Establishment}

Polyhouse production is a capital-intensive technology requiring a substantial investment especially during the initial establishment period. The details of cost components in establishing a poly house are given in Table 1 .

A non-land capital investment of Rs.40,67,814.35 per acre/ $4000 \mathrm{~m}^{2}$ was required for erecting polyhouse. Availed 50 per cent subsidy amount to the total establishment cost was Rs.24,56,186/4000m². The establishment cost has been sanctioned by National Horticultural Mission (NHM) under the Mission on Integrated Development Horticulture (MIDH), Government of India, through the State Horticultural Department. The establishment cost includes, costs on initial land preparation, basic structure GI tubes, low-density UV stabilized polyethylene sheet, 40 mesh nylon shade net, drip irrigation and construction costs. Break-up of these establishment costs indicates that the major cost of establishment was incurred on GI frame with 72.78 per cent followed by land levelling and land preparation cost with 9.95 per cent, it includes initial land preparations costs, preparing bunds and making furrows, weeding, farmyard manure and fertilizer applied to soil, etc. The polythene sheet cost occupied 8.15 per cent and Irrigationfertigation system and equipments, grading/storage room and shade net accounted for $4.74,1.58$ and 1.38 per cent to the total establishment costs, respectively.

\section{Cost of cultivation of capsicum}

The cost, gross and net returns of cut flowers and capsicum in the study area were estimated using the cost concept approach, which is widely being used in India for evaluating crop profitability in production by the Commission on Agricultural Costs and Prices (CACP), Government of India, New Delhi. It could be observed from the Table 2, The average working cost of cultivation of capsicum under poly house was Rs 7,26,825/4000 $\mathrm{m}^{2}$. The break-up of costs indicated that the highest cost was incurred on labour in capsicum cultivation indicating that poly house cultivation is labour intensive. Nearly 21 per cent of the working costs were incurred on labour in capsicum cultivation. Human labour, machine labour, seedlings, manures, fertilizers, plant protection chemicals and miscellaneous cost were the major inputs which cost $A_{1}$ has been incurred. The cost $A_{1}$ was higher 55.19 per cent for capsicum cultivation. In cost $B_{1}$ was cost $A_{1}$ with including the interest on fixed capital excluding the land was 31.81 per cent of the total cost of production of capsicum cultivation. Imputed family labour was estimated around three per cent to the total cost of cultivation. The cost $\mathrm{C}_{3}$ was Rs. 13, $16,996.37 / 4000 \mathrm{~m}^{2}$ for capsicum under protected cultivation. The average yield of capsicum was $38,741.21 \mathrm{kgs}$ and the cost of cultivation of capsicum calculated was Rs 33.94 per $\mathrm{kg}$. The gross return of the cultivated crops found to be Rs. 15,29,502.97 and Net return Rs. 2,12,506.60 for capsicum cultivation.

\section{Cash flows of capsicum production}

The cash inflows and outflows were worked out for the period of five years. Actual costs and returns during 2015-16 for capsicum was documented and used for the cash flows. During this period one crop period was taken. For remaining periods the costs and returns were projected based on the actual costs and returns. The year-wise details on the cost structure are given in Table 3. 
Table.1 Cost of establishment of a poly house structure of capsicum production

\begin{tabular}{|l|l|c|c|c|}
\hline $\begin{array}{l}\text { SI. } \\
\text { No. }\end{array}$ & Particulars & $\begin{array}{c}\text { Cost/ } \mathbf{4 0 0 0} \mathbf{~ m}^{\mathbf{2}} \\
\text { (Rs.) }\end{array}$ & $\begin{array}{c}\text { Percentage } \\
\text { to Total }\end{array}$ & $\begin{array}{c}\text { Life Period } \\
\text { (Years) }\end{array}$ \\
\hline I & Poly house and buildings & & & \\
\hline 1. & Land leveling and land preparation cost & $4,04,747.52$ & 9.95 & 5 \\
\hline 2. & Structural frame - G.I. pipe & $29,60,555.30$ & 72.78 & 20 \\
\hline 3. & Polythene sheet & $3,31,526.87$ & 8.15 & 5 \\
\hline 4. & Shade net & $56,135.84$ & 1.38 & 5 \\
\hline 5. & Grading room/ storage room & $62,237.56$ & 1.53 & 20 \\
\hline 6. & Miscellaneous cost (Incidental charges) & $59,796.87$ & 1.47 & \\
\hline & Subtotal (A) & $\mathbf{3 8 , 7 4 , 9 9 9 . 9 6}$ & $\mathbf{9 5 . 2 6}$ & \\
\hline II & Irrigation system and equipments & $91,932.60$ & 2.26 & 5 \\
\hline 7. & Drip irrigation/Fertigation unit & $9,762.75$ & 0.24 & 5 \\
\hline 8. & Sprayers & $21,152.63$ & 0.52 & 5 \\
\hline 9. & Equipments & $33,762.86$ & 0.83 & 5 \\
\hline 10. & Electrical Installation & $36,203.55$ & 0.89 & 5 \\
\hline 11. & Fence and generator & $\mathbf{1 , 9 2 , 8 1 4 . 3 9}$ & $\mathbf{4 . 7 4}$ & \\
\hline & Subtotal (B) & $\mathbf{4 0 , 6 7 , 8 1 4 . 3 5}$ & $\mathbf{1 0 0 . 0 0}$ & \\
\hline III & Total establishment cost (A+B) & $\mathbf{1 9 , 3 7 , 4 9 9 . 9 8}$ & & \\
\hline 12. & Subsidy from NHM @ 50 \% of A (C) & $\mathbf{2 1 , 3 0 , 3 1 4 . 3 7}$ & & \\
\hline IV & Total establishment cost with subsidy (C+B) & & \\
\hline
\end{tabular}

Table. 2 Cost of cultivation of capsicum under protected cultivation

\begin{tabular}{|c|c|c|c|}
\hline & & \multicolumn{2}{|c|}{ (Rs. $/ 4000 \mathrm{~m}^{2} /$ Year) } \\
\hline S. No & Particulars & Cost & Percentage \\
\hline 1. & Human labour & $2,75,797.81$ & 20.94 \\
\hline 2. & Machine labour & $12,756.84$ & 0.97 \\
\hline 3. & Seedlings & $32,457.65$ & 2.46 \\
\hline 4. & Farmyard manures & $15,457.69$ & 1.17 \\
\hline 5. & Inorganic fertilizer & $22,779.76$ & 1.73 \\
\hline 6. & Plant protection chemicals & $23,186.54$ & 1.76 \\
\hline 7. & Miscellanious cost* & $13,678.45$ & 1.04 \\
\hline 8. & Interest on working capital @7\% & $27,728.03$ & 2.11 \\
\hline 9. & Depreciation on fixed capital & $3,02,842.67$ & 22.99 \\
\hline 10. & Land revenue & 140.00 & 0.01 \\
\hline I & Cost $\mathbf{A}_{1}$ & $7,26,825.44$ & 55.19 \\
\hline 11. & Interest on owned capital (excluding land) @ 12\% & $4,18,962.72$ & 31.81 \\
\hline II & Cost $B_{1}$ & $11,45,788.16$ & 87.00 \\
\hline 12. & Rental value of owned land & $15,000.00$ & 1.14 \\
\hline III & Cost $\mathbf{B}_{2}$ & $11,60,788.16$ & 88.14 \\
\hline 12. & Imputed value of family labour & $36,481.27$ & 2.77 \\
\hline IV & Cost $C_{1}\left(\right.$ Cost $B_{1}+$ Imputed value of family labour $)$ & $11,82,269.43$ & 89.77 \\
\hline V & Cost $C_{2}$ (Cost $B_{2}+$ Imputed value of family labour) & $11,97,269.43$ & 90.91 \\
\hline VI & Cost $C_{3}\left(\right.$ Cost $C_{2}+10 \%$ of Cost $\left.C_{2}\right)$ & $13,16,996.37$ & 100.00 \\
\hline & Average yield $\left(\mathrm{Kg} / 4000 \mathrm{~m}^{2}\right)$ & $38,741.21$ & \\
\hline & Average output price $(\mathrm{Rs} / \mathrm{Kg})$ & 39.48 & \\
\hline & Gross return & $15,29,502.97$ & \\
\hline & Net Return & $2,12,506.60$ & \\
\hline
\end{tabular}

*(Twines, staking, packing material and incidental charges) 
Table.3 Cash flow of costs and returns of tomato and capsicum (Rs. $/ 4000 \mathrm{~m}^{2}$ )

\begin{tabular}{|l|l|l|c|}
\hline S. No & Years & Costs & \multicolumn{1}{|c|}{ Returns } \\
\hline 1. & First year & $40,67,814.37$ & $13,76,552.70$ \\
\hline 2. & Second year & $4,46,600.16$ & $17,58,928.45$ \\
\hline 3. & Third year & $4,88,929.07$ & $18,35,403.60$ \\
\hline 4. & Four year & $5,16,910.12$ & $15,29,503.00$ \\
\hline 5. & Fifth year & $5,60,315.04$ & $11,47,127.25$ \\
\hline
\end{tabular}

Table.4 Financial feasibility in poly house crop cultivation

\begin{tabular}{|l|l|c|}
\hline Sl. No & Economic Indicator & Particulars \\
\hline 1. & Net present worth $\left(\right.$ Rs. $\left./ 4000 \mathrm{~m}^{2}\right)$ & $5,78,156$ \\
\hline 2. & Benefit Cost Ratio & 1.24 \\
\hline 3. & Payback period (Years) & 2.66 \\
\hline 4. & Internal Rate Return (per cent) & $25 \%$ \\
\hline
\end{tabular}

Table.5 Problems faced in capsicum production under protected cultivation

\begin{tabular}{|l|l|c|c|}
\hline S. No & Problems & Garrett Score & Rank \\
\hline 1. & High investment cost & 61.88 & I \\
\hline 2. & Lack of technical guidance & 59.88 & II \\
\hline 3. & Non availability of skilled labour & 59.02 & III \\
\hline 4. & High cost of maintenance & 53.18 & IV \\
\hline 5. & High cost of hired labour & 49.82 & V \\
\hline 6. & Lack of storage facility & 35.58 & VI \\
\hline 7. & Pests and Diseases problem & 32.65 & VII \\
\hline
\end{tabular}

The land preparation and plant material were used in polyhouse is normally replaced every years hence, every year an additional costs to be included. Economic feasibility indicators (PBP, NPV, BCR, and IRR) were worked out for capsicum and feasibility indicators are given in Table 4.

The payback period for polyhouse production of capsicum was found to be less than three years. Total net returns (undiscounted) for five years period was of Rs.15.67 lakhs/ 4000 $\mathrm{m}^{2}$ with an annual average net return of Rs.15.29 lakhs/ $4000 \mathrm{~m}^{2}$. The Net present value (NPV) of the total net returns at 12 per cent discount rate for five years period was Rs
5.78 lakhs/ $4000 \mathrm{~m}^{2}$ with the benefit cost ratio (BCR) of Rs.1.24, Internal rate of return (IRR) in polyhouse production of capsicum likely to be 25 per cent per annum. Therefore, production of capsicum in a polyhouse is highly feasible and profitable.

The farmers in the study area faced several problems in the production of capsicum. Hence it was decided to study the major constraints in capsicum production in the study area. The seven constraints identified by the sample farmers were ranked using Garrett's ranking technique and the details are furnished in the table 5. From the Table 5 that the sample farmers expressed that the high 
investment cost for establishing poly house was the most important reason (61.88) in the protected cultivation, because of majority of the farmers belongs to small and semi medium farmers and their capital accumulation capacity was very low. The Second major constraint in capsicum production was lack of technical guidance for protected cultivation (59.88). The next important problem was non-availability of skilled labour (59.02) followed by high cost maintenance, high cost of hired labour and lack of storage facility because of cold storage construction needs additional investment cost and high maintenance. The least problems was found in protected cultivation were pest and diseases problem.

Cultivation of high value crops is yielding more rather than in the conventional farming system. Vegetable like capsicum yield few fold under protected cultivation. The cost of investment on poly house significantly higher which was Rs. 40.67 lakhs/ $4000 \mathrm{~m}^{2}$, if the cost of investment could be subsidized for instance 50 per cent in the Capsicum grower of this present study showed economically feasible. The financial viability of Capsicum grown under poly house had PBP (2.66 years), NPV (5.78 lakhs/ $4000 \mathrm{~m}^{2}$ ), B-C ratio (1.24) and IRR (25 per cent) revealed that small and marginal farmer could invest on protected cultivation of vegetables. Despite little constrains such as high investment cost and lack of technical skill cultivation of vegetables under protected cultivation supports the farmers to adopt poly house cultivation.

\section{References}

Ali Qamar, Ashfaq Muhammad, and Khan M. T. I., (2016) "An Economic analysis of Off-season Capsicum/Bell pepper Production in Punjab Pakisthan". ARPN
Journal of Agricultural and Biological Science, Vol. 11(11) 424-430.

Brij bala, (2013) "Upliftment of rural economy through protected cultivation", Research paper, Global Research Analysis, 2013, 2 (2) pp 42-43.

Garrett, H. E. and Woodworth, R. S. (1977). "Statistics in Psychology and Education", Vakils Feffer and Simons Pvt. Ltd., Bombay, p.329.

Goncharova, N. A., Van der Vlist, J. A. A. M. and Verstegen, (2004) "Changes in horticulture sector in the Nethetlands", Acta Hort, 655: 319-31.

Horticultural Statistics at a glance (2017), Ministry of Agriculture and Farmers welfare, Govt. of India.

Jensen, M. H., (2002) "Controlled environment agriculture in deserts tropics and temperate regions - A world review", Acta Hort, 578: 19-25.

Kumar, Praveen, Chauhan, R.S. and Grover, R. K., (2016) "Economic analysis of capsicum cultivation under Polyhouse and open field conditions in Haryana", International Journal of Farm Sciences. 6(1) 96-100.

Mathura rai, (2012) "Protected cultivation of vegetables in Indian plains, Book of Vegetable Production under changing climate scenario, Dr. Y.S. Parmer University of Horticulture and forestry, Solan, H.P. 28-36.

Punera, Bhoopesh, Pal, Suresh, Jha, Girish K. and Kumar, Pramod, (2017) "Economics and Institutional aspects of protected cultivation of Carnation in Himachal Pradesh", Agricultural Economics Research Review, 30(1): p. 73-80.

Rai, N., Nath, A., Yadav, D.S. and Patel, K.K., (2004) "Effect of polyhouse on shelf-life of bell pepper grown in Meghalaya", National Seminar on Diversification of Agriculture through 
Horticultural Crops, held at IARI Regional Station, Karnal, pp. S.P. 22.

Sreedhara, D. S., Kerutagi, M. G., Basavaraja, H., Kunnal, L. B. and Dodamani, M. T., (2013) "Economics of capsicum production under protected conditions in Northern Karnataka", Karnataka Journal of Agricultural Sciences, 26 (2): 217-219.

Sreenivasa Murthy, D., Gajanana, T.M., Sudha, M. and Dakshinamoorthy, V., (2007) "Marketing Losses and Their
Impact on Marketing Margin: A case study of Banana in Karnataka", Agricultural Economics Research Review, 20: 47-60.

Tarannum, Hemla Naik B and Zaheer Ahamed B, (2014) "Economic Feasibility and Profitability of Carnation (Dianthus caryophyllus L.) Cultivation under Protected cultivation", International Journal of Science and Nature, vol.5 (2), p 283286.

\section{How to cite this article:}

Senthilkumar S., K. R. Ashok, M. Chinnadurai and Ramanathan S. P. 2018. An Economic Analysis of Capsicum Production under Protected Cultivation in North West Region of Tamil Nadu, India. Int.J.Curr.Microbiol.App.Sci. 7(06): 2276-2283.

doi: https://doi.org/10.20546/ijcmas.2018.706.272 